\title{
СУЧАСНІ МЕТОДИ ТА ЗАСОБИ ОПТИМІЗАЦІЇ ПРОФЕСІЙНОЇ САМОІДЕНТИЧНОСТІ МАЙБУТНЬОГО ПСИХОЛОГА
}

\author{
Інна Бойченко \\ науковий співробітник відділу дослідження проблем молоді \\ Державний інститут сімейної та молодіжної політики \\ 01023, Україна, м. Київ, вул. Еспланадна, 17 а \\ i_boych@ukr.net, http://orcid.org/0000-0002-2607-5612
}

\begin{abstract}
Анотація
Статтю присвячено аналізу результатів апробації засобів ефективного становлення професійної самоідентичності майбутніх психологів та ії складників, перш за все через активізацію процесів особистісного саморозвитку, формування уявлень про себе як професіонала, розвиток когнітивного, емоційно-оцінного, мотиваційного та поведінкового компонентів професійної самоідентичності в цілому. Завдання формувального експерименту з оптимізації професійної самоідентичності психологів включало: 1) розроблення програми оптимізації професійної самоідентичності для майбутніх психологів; 2) приведення неадекватно завищеного рівня самооцінки досліджуваних студентів-психологів під час навчально-професійної підготовки у адекватний стан за допомогою використання програми оптимізації; 3) зниження рівня тривожності та негативно-емоційного переживання майбутніх психологів під час навчання за допомогою програми; 4) підняття рівня пізнавальної активності майбутніх психологів під час навчання за допомогою програми. Розроблена тренінгова програма оптимізації становлення професійної самоідентичності майбутніх психологів. Вона містила такі активні соціально-психологічні методи: дискусії, рольові ігри, психогімнастичні прийоми, тренінги з домашніми завданнями, методами індивідуальної самостійної роботи. Мета тренінгової програми: коригування рівнів розвитку психолого-педагогічних складових майбутніх психологів у ході становлення їхньої професійної самоідентичності. Завдання тренінгової програми: 1) опанування студентами-психологами знань про професійну самоідентичність, що необхідна для їх ефективної майбутньої діяльності; 2) ознайомлення майбутніх психологів із методами та прийомами діагностики психологічних характеристик особистості, які впливають на становлення професійної самоідентичності; 3) оволодіння вміннями та навичками виконання конкретних професійних завдань, які виникають у процесі здійснення майбутньої діяльності, використовуючи для цього власні професійно значущі якості. Перший модуль був спрямований на підвищення пізнавальної активності майбутніх психологів, другий - на корекцію їхньої самооцінки, а третій - на корекцію їх емоційного стану. Для визначення ефективності програми оптимізації процесу професійної самоідентичності майбутніх психологів, нами було здійснено порівняльний аналіз рівнів розвитку особистісних складових у контрольній та експериментальній групах.
\end{abstract}

Ключові слова: професійна самоідентичність, особистісні складові професійної самоідентичності, компоненти особистісних складових професійної самоідентичності, тренінгова програма формування професійної самоідентичності, майбутній психолог. 


\section{Вступ}

Сучасні зміни в суспільних процесах актуалізують необхідність пошуку ефективних методів та засобів професійного становлення особистості в різних сферах життя, що грунтуються на осмисленні й утвердженні власної ідентичності та перспективах самореалізації.

Відповідно цього особливо зростає практична значущість проблем професійного становлення майбутніх фахівців професій «людина-людина» й психологів, зокрема. На сьогоднішній день з'являються різні новітні галузі професійної діяльності практичної психології, які втілюються в різноманітні служби, кабінети соціально-психологічного спрямування. Натомість, вітчизняна школа фахової підготовки психологів переважно залишається в сфері теоретичної компетенції з незначним вкрапленням практики. Причинами цього можуть бути: невідповідність стану системи навчально-професійної підготовки означених спеціалістів, зумовленим стрімким зростанням потреб психологічної практики в українському суспільстві; необхідність вирішення комплексу завдань 3 підвищення профпридатності студентів, розв'язання яких сприятиме усвідомленому вибору професії, врахуванню їх індивідуальних особливостей, особливостей становлення професійної самоідентичності майбутніх психологів.

Визначення цих особливостей, підбір актуальних методів та засобів формування особистості професіонала $є$ неодмінною передумовою та складовою процесу підготовки таких спеціалістів. Крім того, успішне розв'язання проблем професійної самоідентичності майбутніх психологів чималою мірою сприятиме й становленню професійної свідомості та самосвідомості майбутніх фахівців з психології, набуттю у них системи сучасних світоглядних цінностей, професійно значущих якостей, умінь, навичок, автентичних самооцінок, самовизначення та, зрештою, на цій основі, - продуктивної самореалізації.

Отже, рівень професійної підготовки спеціалістів-психологів визначається, з одного боку, можливостями вищої освіти в підготовці майбутнього фахівця, а, з іншого, - вимогами до психологічної діяльності. Вирішення означеної проблеми зумовлює необхідність пошуку такої фахової моделі, яка б поєднувала обидва аспекти й відповідала сучасним вимогам. Особливо гостро ці питання постають протягом професійної підготовки фахівців із психології у навчальних закладах.

Так, нагальним для професійної підготовки майбутніх психологів залишається питання навчання на початкових курсах, як першого етапу входження в професію та формування профпридатності студентів. Правильно підібрані методи розвитку й корекції індивідуальних особливостей студентів-психологів сприятимуть процесу конкретизації та обрання ними подальшого спеціалізаційного напрямку в професії, визначенню притаманної саме для них психологічної галузі, в межах якої майбутній психолог виявить найбільшу ефективність i конкурентоспроможність, надаючи підтримку іншим. Оскільки розвиток і корекція цих особливостей $\epsilon$ необхідною й значущою передумовою процесу підготовки фахових психологів, видається актуальним визначення специфіки розвитку професійної самоідентичності майбутнього психолога. Останнє, за нашим переконанням, є інтегративним особистісним утворенням, адже об'єднує ряд векторів особистісного розвитку, а саме, визначення і прийняття своєї ролі в професійній групі, окреслення міри професійної компетентності, спроможність до побудови перспективного плану фахової самореалізації тощо. 
3 цього питання існують певні дослідження, присвячені проблемам оволодіння програмою професійної підготовки, у яких розглянуті деякі технологічні питання підготовки фахівців, запропоновані різні моделі структури особистості практикуючого психолога, висвітлені умови особистісного розвитку психолога-практика (Є.Ю. Альошина, М.О. Амінов, В.Ю. Большаков, О.Ф. Бондаренко, Ж.П. Вірна, В.П. Захаров, Ю.М. Смельянов, О.Г. Солодухова, В.Г. Панок, Л.А. Петровська, Н.І. Пов’якель, Н.В. Пророк, Т.М. Титаренко, Л.I. Уманець, Н.В. Чепелєва, I.М. Юсупов, Т.С. Яценко та ін.). I передусім привернуто увагу до пошуку шляхів та засобів подолання існуючого нині розриву між теоретичним навчанням та практичною діяльністю майбутніх фахівців 3 прикладної психології (В.Г. Панок, Н.В. Чепелєва, Н.І. Пов'якель, Л.Г. Терлецька, Т.М. Титаренко).

У психолого-педагогічній літературі $є$ також чимало досліджень, у яких розглянуто різні зрізи проблеми професійного становлення. Серед них - гуманістичний підхід у навчально-виховному процесі Г.О. Балла, професійні здібності психологів Н.В. Бачманової, Н.Р. Бітянової, психодіагностичні принципи підготовки шкільних психологів О.Д. Божович, ціннісно-смислові утворення особистості як внутрішні детермінантами пі розвитку М.Й. Боришевського, Л.П. Виговської, становлення особистості професіоналів у межах акмеологічного підходу А.А. Деркача, внутрішньо-особистісні перетворення в професійному становленні С.Д. Максименка, теоретичні передумови психологічної практики Т.С. Яценко та ін. Важливі положення щодо становлення особистості професіонала сформульовані в межах акмеологічного підходу Н.В. Кузьміної, А.О. Деркача, А.О. Реана, Л.М. Карнозової, О.П. Ситникова та ін.

Пошуки специфіки професійної підготовки, професіоналізму, психологічної та професійної готовності майбутнього психолога здійснювались у межах таких наукових підходів, як особистісно-орієнтованого (І.Д. Бех, І.С. Булах, К. Роджерс, В. Франкл, Е. Фромм, І.С. Якиманська та ін.), ціннісно-смислового (І.Д. Бех, А.О. Деркач, О.С. Сапогова, Л.В. Баєва, Є.О. Клімов та ін.) та особистісно-діяльнісного (О.М. Леонтьєв, Б.Г. Ананьєв, О.В. Бондаревська, А.О. Деркач, М.І. Д'яченко, Л.О. Кандибович, В.В. Серіков). Проте, вивчення проблеми становлення професійної самоідентичності майбутніх психологів у ході їх навчально-професійної підготовки, а, саме особливостей розвитку та корекції іiі особистісних складових (пізнавальної активності, самооцінки та емоційної сфери) не здійснювалося раніше в межах особистісно-професійного підходу.

Мета дослідження - 3'ясування ефективності впливу тренінгової програми формування професійної самоідентичності на іiі становлення в майбутніх психологів. Завдання дослідження: 1) визначити теоретичні підходи до проблеми становлення професійної самоідентичності в умовах фахової підготовки; 2) дослідити психологопедагогічні особливості впливу програми формування професійної самоідентичності на становлення останньої у майбутніх психологів у ході навчально-професійної діяльності.

\section{Методи дослідження}

Для розвитку й корекції особливостей становлення професійної самоідентичності майбутніх психологів у дослідженні була використана тренінгова програма формування професійної самоідентичності. Вона містила ряд модулів, які були спрямовані на підвищення пізнавальної активності, корекцію самооцінки та емоційного стану майбутніх психологів. Під час проведення програми було використано такі методи та вправи: анкетування, рольові ігри та дискусії, розбір кейсів, вправи, спрямовані на розвиток пізнання професії й себе в ній, формування адекватної самооцінки майбутніх психологів; формування позитивного 
самоприйняття учасників програми, ставлення до себе й інших, а також на розвиток різних стилів поведінки під час цілеспрямованої, впевненої діяльності з метою вдосконалення; розробка алгоритму успішного психолога (опис, твір, перелік рис, схематизація); формування колажів з метою створення портрету «успішного психолога».

Програма формування професійної самоідентичності майбутніх психологів складалася із трьох одноденних тренінгових модулів (один раз на тиждень по шість годин), а також з трьох самостійних домашніх завдань, вступного та завершального заняття.

Так, розроблена тренінгова програма складалася із 3-х модулів та була розрахована на 45 годин (1,5 кредити), з яких 30 годин аудиторної роботи (2 академічні години - вступ до тренінгу, 3 тренінгові сесії по 6 годин; 2 академічні години - завершення тренінгу, 6 академічних годин на перевірку та обговорення домашніх завдань) та 17 годин самостійної роботи (для виконання творчих завдань та рефлексії).

Мета тренінгової програми: коригування рівнів розвитку психологічних складових професійної самоідентичності майбутніх психологів у ході її становлення.

Завдання тренінгової програми:

1. Опанування студентами-психологами знаннями про професійну самоідентичність, як необхідну для ефективної майбутньої діяльності.

2. Ознайомлення майбутніх психологів із методами та прийомами діагностики психологічних характеристик особистості, які впливають на становлення професійної самоідентичності.

3. Оволодіння вміннями та навичками виконання конкретних професійних завдань, які виникають у процесі здійснення майбутньої діяльності, використовуючи для цього власні професійно значущі якості.

Перший модуль був спрямований на підвищення пізнавальної активності майбутніх психологів, другий - на корекцію самооцінки, а третій - на корекцію емоційного стану. Також кожен модуль вміщував у собі такі завдання та форми їхньої реалізації, що сприяли розвитку мотиваційного, когнітивного, емоційного та операційного компонентів. Варто зазначити, що всі завдання тренінгової програми були побудовані з урахуванням специфіки майбутньої професійної діяльності психологів.

Зазначаємо, що лише системна реалізація всіх трьох тематичних модулів забезпечують досягнення в цілому поставленої мети тренінгової програми.

Перед початком тренінгу проведено вступне заняття, на якому студентів було ознайомлено з програмою тренінгу, метою та завданнями; учасники озвучили свої очікування від цієї програми, обговорили графік зустрічей, прийняли правила роботи групи та заповнили вхідну анкету.

Загалом кожне заняття було спрямоване на формування конкретного компонента структури професійної самоідентичності (мотиваційного, когнітивного, емоційно-оцінного, поведінкового) майбутніх психологів.

Ефективність впровадженої програми визначалася за допомогою наступних методів. Так, за допомогою тесту «Самооцінка» (Будасси, 1972) та методики «Опитувальник САН» (Рогов, 1999) було визначено позитивні зміни в мотиваційному компоненті професійної самоідентичності майбутніх психологів, у ставленні до себе в професії та до самої професії. Для з'ясування якісних змін у когнітивному й операційному компонентах професійної самоідентичності досліджуваних (зміни в сприйнятті себе, як потенційно кращих фахівців, здатних впоратися з низкою професійних завдань; здобуття нового практичного досвіду, кращого розуміння природи різних поведінкових реакцій, організації своєї праці та інших, 
нестандартного вирішення професійних завдань) була використана методика «Вивчення професійної ідентичності (МВПI)» Л.Б. Шнейдер (Шнейдер, 2007) та опитувальник дослідження тривожності Спілбергера (в адаптації Андреєвої) (Дубровина, Акимова \& Борисова, 1995).

\section{Результати та дискусії}

На сьогодні в умовах ринкової економіки в ході професійного становлення особистості набуває особливої актуальності значення професійно-психологічного потенціалу й професійної мобільності фахівця. Ці вимоги $є$ провідними й у підготовці майбутніх психологів. Отже, постає необхідність створення ефективних соціально-психологічних умов у процесі навчально-психологічної підготовки психологів. Однією 3 таких умов $\epsilon$ психологічний супровід професійного становлення майбутніх фахівців.

Теоретичний аналіз такого супроводу найбільш змістовно, на нашу думку, подано Е.Ф. Зеєром (Зеер, 2005). На думку автора, психологічний супровід, це поєднання в одне ціле процесу вивчення, формування, розвитку та корекції професійного становлення особистості 3 урахуванням психологічних особливостей кожної стадії, а також можливості особистості нести відповідальність за своє професійне життя (Зеер, 2005: 284). Достатньо наближено до вказаного попередньо, О.О. Євдокімова головну мету психологічного супроводу визначає через створення умов, сприятливих для розвитку особистості на всіх етапах особистіснопрофесійного розвитку, реалізації актуальних і потенційних можливостей особистості, ефективного засвоєння нових знань у сфері навчальної і професійної діяльності, побудови життєвої стратегії, оптимізації професійного й особистісного зростання (Свдокімова, 2009).

Вивченням сучасного тренінгового забезпечення психологічного супроводу професійного становлення фахівця займається Е.Е. Симанюк (Сыманюк, 2005: 197-246). Автором розроблено комплекс тренінгів, які цілеспрямовано можуть вирішувати завдання даного супроводу: 1) «Тренінг корекції стратегії подолання криз професійного становлення особистості»; 2) «Тренінг профілактики та корекції вивченої безпорадності»; 3) «Тренінг формування професійної ідентичності».

У нашому дослідженні психологічний супровід у вигляді наставництва здійснив вагомий вплив на ефективність набуття професійної самоідентичності в навчальнопрофесійній діяльності. Саме професійна самоідентичність у процесі професіогенезу забезпечує цілісність особистості та задоволення потреб суспільного розвитку в тріаді «особистість-діяльність-соціум» (Кудрявцев, 1981; Бодров, 1991; Цільмак, 2013).

Професійна самоідентичність особистості визначається психологами через сформовані навчально-професійні інтереси, цілі, очікування, дії, досягнення, результати, якості, які складають потенціал професіонала, цінностей майбутньої професійної діяльності тощо (Варбан, 1998).

Формування висококваліфікованого спеціаліста передбачає його особистісне становлення як суб'єкта діяльності й співпадає з періодом юнацтва або першим періодом дорослості, який відрізняється складністю становлення особистісних рис (Б.Г. Анан'єв, І.С. Кон, В.М. Лісовський та ін.).

Зокрема I.C. Кон, як представник стадіального напрямку становлення спеціаліста, розуміє професійне самовизначення як багатогранний та багатоступеневий процес, характерною складовою якого є професійна самоідентифікація (Кон, 1980). До істотних факторів професійного самовизначення автор відносить вік, рівень інформованості та рівень домагань. 
На думку О.М. Леонтьєва, професійне становлення особистості ототожнюється зі становленням особистісних смислів, усвідомленням себе в системі суспільних зв'язків. Зазначене попередньо є проявом професійної самоідентифікації (Леонтьев, 1975).

Для розв'язання проблеми професійно-особистісної підготовки психолога-практика О.Ф. Бондаренко задіював чотири взаємопов'язані аспекти: побудову теоретичної моделі спеціаліста, яка передбачала розробку стандартів (норм і нормативів), вимог до особистості та діяльності практичного психолога; первинний відбір професійно придатних кандидатів; розробку змісту навчання і розвитку психологів-практиків; розв'язання проблем власне професійного самовизначення спеціалістів, провідною 3 яких $є$ проблема професійної ідентифікації (Бондаренко, 1996).

В.А. Семиченко доводить, що підготовку до професійної діяльності варто розглядати як своєрідний засіб розвитку особистості. I саме заклад вищої освіти має забезпечити цей розвиток. Методологічні основи професійної підготовки психологів вчена описувала як ієрархію особистісних цінностей (як пріоритетних) - пошук свого місця в професійнорольовій структурі суспільства, професійних - повноцінне включення в професійно-рольові відносини та кваліфікаційних (якість сформованості професійних умінь і навичок) інтеріоризація спеціальних знань, навичок, умінь, оволодіння техніками, технологіями, прийомами спеціалізації (Семиченко, 2000). Зміст цих процесів, у нашому випадку, відображає рівні, складові процесу становлення професійної самоідентичності особистості.

I.А. Дружиніна, у свою чергу, приділяє увагу вивченню особистісного компоненту в професійному розвитку студентів-психологів. На її думку, в процесі професійної підготовки психологів у ЗВО важливо приділяти належну увагу особистісному, емоційному розвитку, позитивному ставленню до себе, оскільки саме процеси когнітивного й індивідуального розвитку в сукупності створюють основу для формування професійної ідентичності, що $€$ частиною самосвідомості, самовизначення особистості (Дружиніна, 2010).

Згідно поглядів Г.В. Ложкіна та Н.Ю. Волянюк (Ложкін \& Волянюк, 2008: 123-130), професійна ідентичність $є$ одним із провідних критеріїв становлення професіонала. Усвідомлюючи необхідність формування професійної ідентичності, фахівець сам вирішує в якій мірі варто приймати певну форму діяльності, певний спосіб професійної взаємодії й себе як професіонала.

Дослідження, присвячені вивченню самоідентичності особистості в процесі професійної підготовки (Adamek, 1971), показали, що особистісна самоідентичність у професійному навчанні в ряді випадків відбувається стихійно, має не завжди передбачувані наслідки й може призводити до непередбачуваних негативних результатів, навіть до неадекватної самоідентичності майбутнього спеціаліста в професійному навчанні.

Проблеми формування професійної самоідентичності в повному обсязі актуальні в процесі підготовки майбутніх психологів. Дослідження показують, що процес самоідентифікації майбутніх психологів є недостатньо ефективним. Це виражається в тому, що майбутні спеціалісти недостатньо ідентифікують себе з професійним ідеалом (Джемс, 1982), не повністю усвідомлюють свою належність до психологічної професії та їм важко визначити в чому полягає їх особистісно-професійна індивідуальність (Еly, 1997).

Отже, виходячи з результатів досліджень вітчизняних та зарубіжних вчених, можна стверджувати, що професійна самоідентичність, як частина особистісно-професійної ідентичності, постає системним, динамічним, рівневим явищем, що характеризує прийняття особистістю професійних ціннісних позицій у професійному самовизначенні за теоретичної підготовки та практичних спроб у майбутній професії на етапі навчання у ЗВО. Професійна 
самоідентичність $є$ активним особистісно-професійним проявом усвідомленого ставлення до обраної професії, позаяк оцінювання професійної самоідентичності відбувається на основі суб'єктивних показників, включаючи професійну самооцінку, професійне самовизначення, задоволеність працею, професією, кар'єрою, собою тощо. А також фахівець сам вирішує, в якій мірі варто приймати певну форму діяльності, певний спосіб професійної взаємодії й себе як професіонала (Поваренков, 1991; Ложкін \& Волянюк, 2008: 123-130). Розвинені ж структури профідентичності, на основі яких можна говорити про професійну самоідентичність, дозволяють адаптуватися у професійному середовищі й успішно виконувати практичні професійні обов'язки фахового психолога.

Метою констатувальної частини емпіричного дослідження постало розкриття психологічних особливостей розвитку професійної самоідентичності майбутніх психологів під час здобуття фахової освіти. В експерименті брало участь 178 осіб.

За результатами розробленої нами анкети «Професійний вибір та навчальнопрофесійна адаптація майбутніх психологів» та методики «Вивчення професійної ідентичності (МВПІ)» Л.Б. Шнейдер (Шнейдер, 2007), тесту «Самооцінка» (Будасси, 1972), методики «Опитувальник САН» (Рогов, 1999), опитувальника дослідження тривожності Спілбергера (в адаптації Андреєвої) (Дубровина, Акимова \& Борисова, 1995), були виокремлені студенти-психологи, які увійшли в експериментальну групу. Респондентами були студенти III-IV-x курсів Інституту педагогіки та психології Національного педагогічного університету імені М.П.Драгоманова та V-x курсів психологічного факультету імені Т.Г. Шевченка та факультету англійської мови Національного лінгвістичного університету.

В результаті нашого дослідження за допомогою низки методів: «Методика дослідження самооцінки особистості» (авт. С. Будассі); Методика «Самооцінка психічного стану: самопочуття, загальна активність, настрій (САН)» (авт.: В.А. Доскін, Н.А. Лаврентьєва, В.Б. Шарай, М.П. Мірошников); «Шкала реактивної та особистісної тривожності» (розроблена Ч.Д. Спілбергером, адаптована Ю.Л. Ханіним), було виокремлено особистісні складові професійної самоідентичності, які мали недостатній рівень розвитку та невідповідний стан прояву. Такими особистісними складовими профідентичності стали пізнавальна активність, самооцінка та емоційний стан майбутніх психологів.

Проведене констатувальне дослідження виявило, що 38,9\% досліджуваних студентівпсихологів знаходяться у стані мораторію їхньої професійної ідентичності. 70,02\% досліджуваних з неадекватно завищеним рівнем самооцінки, 78,9\% майбутніх психологів мали середній рівень тривожності та лише 20,08 \% досліджуваних мали високий рівень пізнавальної активності.

Зазначені складові досліджувалися на констатувальному та формувальному етапах за допомогою таких методів: тесту «Самооцінка» (Будасси, 1972) та опитувальника дослідження тривожності Спілбергера (в адаптації Андреєвої) (Дубровина, Акимова \& Борисова, 1995).

Загальна сукупність випробуваних на етапі формувального експерименту - 62 особи. Експериментальна група складалася 332 студентів віком від 19 до 22 років (студентипсихологи). Контрольна група складалась із 30 студентів віком від 19 до 26 років (студентименеджери). Друга група досліджуваних була нами сформована для порівняння, 3 метою виокремлення тих психологічних особливостей формування професійної самоідентичності, що властиві саме майбутнім психологам, i не $\epsilon$ типовими для процесу професійного становлення будь-якого іншого фахівця, незалежно від його спеціалізації.

Усі учасники дослідження - студенти-психологи та студенти-менеджери управління третього-п’ятого курсів Національного педагогічного університету імені М.П. Драгоманова. 
Студентів-психологів третього-четвертого курсів було обрано свідомо, адже саме на цей період припадає екватор фахової підготовки, й у студентів починає формуватися образ майбутньої професії через вивчення дисциплін професійного циклу та уявлення про психолога-професіонала окреслюється не тільки в теоретичному, а й почасти в практичному вимірі.

3 метою експериментального впливу на студентів ми розробили тренінгову програму формування професійної самоідентичності майбутніх психологів III-V-x курсів (авт. І. Бойченко), яка була зорієнтована на розвиток і корекцію особистісних складових професійної самоідентичності майбутніх психологів. Вона включала такі напрямки тренінгової роботи: підвищення рівня пізнавальної активності, що полягає в опануванні навичками ефективної комунікації, активного слухання, умінні чітко розуміти цілі й наслідки своїх дій, актуальні потреби; корекції самооцінки (розвиток вміння позитивного і адекватного оцінювання) й корекції емоційного стану (оволодіння навичками впевненої поведінки в міжособистісних відносинах).

Порівняльний аналіз психологічних особливостей професійної самоідентичності майбутніх психологів III-V курсів у процесі ії становлення в експериментальній групі після впровадження тренінгової програми показав, що існують статистично значущі відмінності до та після впливу за всіма компонентами особистісних складових. У таблицях 1 та 2 показано результати діагностичних зрізів до та після формувального експерименту в експериментальній та контрольній групах. Порівняння отриманих результатів здійснювалося за допомогою статистичного аналізу за G-критерієм знаків і критерієм $\chi^{2}$.

Таблиия 1

Кількісні показники рівнів розвитку особистісних складових професійної самоідентичності майбутніх психологів до та після формувального експерименту

\begin{tabular}{|l|c|c|c|c|c|c|}
\hline \multirow{3}{*}{ Групи } & \multicolumn{3}{|c|}{$\begin{array}{r}\text { Рівні та показики розвитку особистісних складових професійної } \\
\text { самоідентичності майбутніх психологів } \\
\text { (кількість досліджуваних, у \%) }\end{array}$} \\
\cline { 2 - 6 } & \multicolumn{5}{|c|}{$\begin{array}{c}\text { До формувального } \\
\text { експерименту формувального } \\
\text { експерименту }\end{array}$} \\
\cline { 2 - 7 } & Низький & Середній & Високий & Низький & Середній & Високий \\
\hline $\begin{array}{l}\text { Експериментальна } \\
\text { група }\end{array}$ & 21,3 & 49,7 & 29,0 & 2,6 & 47,1 & 50,3 \\
\hline Контрольна група & 20,3 & 50,1 & 29,6 & 16,0 & 51,4 & 32,6 \\
\hline
\end{tabular}

Як бачимо з порівняльного аналізу результатів, поданих у табл. 1, до формувального експерименту (1 зріз) між експериментальною та контрольною групами відсутні істотні відмінності в рівнях розвитку особистісних складових професійної самоідентичності. Результати після формувального експерименту (2 зріз) в експериментальній групі свідчать про наявність вираженої позитивної динаміки показників особистісних складових профідентичності майбутніх психологів. У контрольній групі динаміка цих показників не $\epsilon$ статистично значущою.

Аналіз результатів впровадження програми розвитку особистісних складових професійної самоідентичності майбутніх психологів довів її ефективність. Це підтверджується тим, що в експериментальній групі між результатами першого та другого зрізів були зафіксовані статистично значущі відмінності в рівнях особистісних складових професійної 
самоідентичності майбутніх психологів: зростання високого рівня розвитку з $29,0 \%$ до $50,3 \%$, незначне зменшення середнього з 49,7\% до 47,1\% та зменшення низького рівня - $321,3 \%$ до $2,6 \%(\mathrm{p}<0,05)$.

У контрольній групі, за результатами першого та другого зрізів, констатовано незначну розбіжність, яка не є статично значущою і в цілому не позначається на рівнях розвитку особистісних складових професійної самоідентичності майбутніх фахівців. Зокрема, дещо зменшилася кількість досліджуваних студентів з низьким рівнем (із 20,3\% до 16,0\%), та було констатовано незначне збільшення досліджуваних із високим (з 29,6\% до 32, 6\%) та середнім ( з 50,1\% до 51,4\%) рівнями.

Отже, можемо констатувати, що під час апробації програми розвитку та корекції особистісних складових професійної самоідентичності майбутніх психологів збільшилася кількість досліджуваних з високим рівнем та зменшилася із середнім та низьким рівнями. Як наслідок, студенти із експериментальної групи мають адекватну самооцінку, краще орієнтуються в особливостях майбутньої професійної діяльності, розкривають власний потенціал, вважають себе спроможними відкритися новому досвіду (різні види практики), пізнати себе. Здобуті під час тренінгу комунікативні навички та навички активного слухання відкрили досліджуваним (учасникам) нові стратегії взаємодії з іншими, можливості надання допомоги іншим, додали їм впевненості та віри у власні сили в пізнавальній діяльності та під час набуття професійних знань. Останнє сприяє досягненню збалансованості дій зовнішніх і внутрішніх мотивів у виборі професії.

Наступний порівняльний аналіз результатів дослідження першого (до початку формувального експерименту) та другого (після завершення формувального експерименту) зрізів в експериментальній та контрольній групах був спрямований на вивчення змін у рівнях розвитку компонентів особистісних складових професійної самоідентичності майбутніх психологів: мотиваційного, когнітивного, операційного. Узагальнені результати порівняльного аналізу за рівнями розвитку особистісних складових в експериментальній групі представлено в табл. 2.

Таблиия 2

\section{Порівняльний аналіз за рівнями розвитку особистісних складових професійної самоідентичності майбутніх психологів в експериментальній групі до та після формувального експерименту}

\begin{tabular}{|c|c|c|c|c|c|c|}
\hline \multirow{3}{*}{ Компоненти } & \multicolumn{6}{|c|}{$\begin{array}{c}\text { Рівні та показники розвитку особистісних складових професійної } \\
\text { самоідентичності майбутніх психологів } \\
\text { (кількість досліджуваних, у \%) }\end{array}$} \\
\hline & \multicolumn{3}{|c|}{$\begin{array}{c}\text { До формувального } \\
\text { експерименту }\end{array}$} & \multicolumn{3}{|c|}{ Після формувального експерименту } \\
\hline & Низький & Середній & Високий & Низький & Середній & Високий \\
\hline Мотиваційний & 21,2 & 33,6 & 45,2 & 3,2 & 29,0 & 67,7 \\
\hline Когнітивний & 24,4 & 43,4 & 32,2 & - & 61,3 & 38,7 \\
\hline Операційний & 16,1 & 54,8 & 29,0 & 3,2 & 41,9 & 54,8 \\
\hline
\end{tabular}

Як видно з таблиці 2, відбулося зростання показників високого рівня в усіх компонентах особистісних складових профідентичності майбутніх психологів та зниження показників низького та середнього рівнів, виключення становить когнітивний компонент, де після проведення експерименту в досліджуваних низького рівня не виявлено, а середній рівень 
розвитку зазначеного компоненту профідентичності досліджуваних склав 61,3\%, тоді як до експерименту становив 43,4\%.

У цілому можна констатувати, що проведений порівняльний аналіз результатів дослідження впровадження розробленої програми свідчить про позитивні зміни в розвитку особистісних складових професійної самоідентичності майбутніх психологів експериментальної групи, серед яких, на нашу думку, необхідно відзначити такі:

1. Зміни мотиваційного компоненту свідчили про те, що здобуття студентами певних професійних компетенцій позитивно впливає на переосмислення себе, насамперед, як професіонала. Майбутні психологи почали глибше розуміти специфіку обраної професії, увиразнився зв'язок особа - провідна діяльність - внутрішній сенс.

2. Розвиток складових когнітивного компоненту в майбутніх фахівців сприяло оптимістичному самосприйманню в професійному контексті, актуалізації ентузіазму під час розв'язання життєвих задач. Після успішного виконання різноманітних тренінгових завдань, спрямованих на розвиток особистісних складових професійної самоідентичності, майбутні психологи почали себе сприймати як потенційно кращих фахівців, здатних впоратися з низкою професійних завдань.

3. Зміни в операційному компоненті свідчили про здобуття нового практичного досвіду під час виконання вправ, кращого розуміння природи тих чи інших поведінкових реакцій, організації своєї праці та інших учасників групи, нестандартного вирішення професійних завдань.

\section{Висновки}

Отже, за результатами експериментального вивчення проблеми становлення професійної самоідентичності майбутніх психологів, ми дійшли висновку стосовно того, що зміни в їі мотиваційному, когнітивному та операційному компонентах, отримані за рахунок впровадження програми формування самоідентичності майбутніх психологів у навчальнопрофесійний процес, є одними з визначальних напрямків підготовки майбутніх спеціалістів у професіях сфери «людина-людина». Розвивально-корекційний вплив даної програми дозволяє переосмислити себе як професіонала, набути оптимістичного самосприйняття у професійному контексті, нового практичного досвіду, вміння нестандартного вирішення професійних завдань.

Перспективи подальших досліджень будуть зорієнтовані на визначення факторної ваги структурних компонентів професійної самоідентичності майбутнього психолога, що мають найбільшу практичну значущість і варіативність впливу на становлення цього інтегративного особистісного утворення майбутнього психолога.

\section{Література}

1. Бондаренко, О.Ф. (1996). Психологічна допомога особистості. Харків : Фоліо.

2. Будасси, С.А. (1972). Самооценка личности. Практические занятия по психологии. А.В. Петровского (Ред.), (с.30-37). Москва.

3. Варбан, М.Ю. (1998). Рефлексія професійного становлення в юнацькому віці. Практична психологія та сочіальна робота, 6-7, 80-83.

4. Деркач, А.А., \& Селезнева, Е.В. (2007). Акмеология в вопросах и ответах: Учебн. пособие. Москва : МПСИ, Воронеж : НПО МОДЭК.

5. Джемс, У. (1982). Личность. Ю.Б. Гиппенрейтер \& А.А. Пузырей (Ред.), Психология личности (с.61-70). Москва : Издательство МГУ. 
6. Дружиніна, І.А. (2010). Місце професійної ідентичності та ідентифікації у професійному просторі практичного психолога. Вісник Харківського національного педагогічного університету імені Г.С. Сковороди. Психологія, 37, 99-108. Харків : ХНПУ.

7. Дубровина, И.В., Акимова, М.К., \& Борисова, Е.М. (1995) Рабочая книга школьного nсихолога. И.В. Дубровиной (Ред.). Москва : Международная педагогическая академия.

8. Свдокімова, О.О. (2009). Психологічні засади вищої технічної освіти. (Монографія). Харків : Нове слово.

9. Зеер, Э.Ф. (2005). Психология профессий (учебное пособие). Москва : Академический Проект, Фонд «Мир».

10. Кокун О.М. (2012). Психологія професійного становлення сучасного фахівия. (Монографія). Київ : ДП «Інформаційно-аналітичне агенство».

11. Кон, И.С. (1980). Психология старшеклассника. Москва : Просвещение.

12. Леонтьев, А.Н. (1975). Деятельность. Сознание. Личность. Москва : Политиздат.

13. Ложкін, Г.В., \& Волянюк, Н.Ю. (2008) Професійна ідентичність в контексті маргінальної поведінки. Соціальна психологія, 3, 123-130

14. Поваренков, Ю.В. (1991). Психология профессионального становления личности (основы психологической конщепции профессионализащии). Курск : Издательство КГПИ.

15. Рогов, Е.И. (1999). Настольная книга практического психолога (учеб. пособие 2-е изд., перераб. и доп. ). Книга 2: Работа психолога со взрослыми. Москва : Гуманитарное издательство: Центр ВЛАДОС.

16. Семиченко, В.А (2000). Пріоритети професійної підготовки: діяльнісний чи особистісний підхід. Неперервна професійна освіта: проблеми, пошуки, перспективи (Монографія). І.Я. Зязюн (Ред.). (с. 176-203) Київ : Віпол.

17. Сыманюк, Э.Э. (2005). Психологические барьеры профессионального развития личности. (Монография). Москва : Московский психолого-социальный институт.

18. Шнейдер, Л.Б. (2007). Личностная, гендерная и профессиональная идентичность: теория и методы диагностики. Москва : Изд-во Моск. соц.-психол. ин-та.

19. Adamek, R.L. (1971). Social Structure, Identification and Change in Treatment-Oriented Institution. Socialization, 162-188.

20. Barbour, J., \& Lammers, J. (2015) Measuring professional identity: a review of the literature and a multilevel confirmatory factor analysis of professional identity constructs. Journal of Professions and Organization, 2(1), 38-60. https://doi.org/10.1093/jpo/jou009

21. Ely, J.D. (1997). Community and the Politics of Identity: Toward the Genealogy of a Nation State Concept. Stanford Humanities Review, 5 (2). Режим доступу: http://www.stanford.edu/group/SHR/

22. Neary, S. (2014). Professional Identity: What I Call Myself Defines Who I am. Career Matters, 2(3), 14-15.

23. Pratt, M., Rockmann, K., \& Kaufmann, J. (2006). Constructing Professional Identity: The Role of Work and Identity Learning Cycles in the Customization of Identity among Medical Residents. Academy Of Management Journal, 49(2), 235-262. https://doi.org/10.5465/amj.2006.20786060

24. Waterman, A.S. (1982). Identity development from adolescence to adulthood: Anextension of theory and a review. Devel. Psychology, 3 (18), 341-358. https://doi.org/10.1037/0012$\underline{1649.18 .3 .341}$

\section{References}

1. Bondarenko, O.F. (1996). Psykholohichna dopomoha osobystosti [Psychological assistance of the individual]. Kharkiv : Folio [in Ukrainian].

2. Budassi, S.A. (1972). Samoocenka lichnosti [Self-esteem of personality]. Prakticheskie zanjatija po psihologii [Practical classes in psychology]. A.V. Petrovskogo (Red). Moskow [in Russian].

3. Varban, M.Iu. (1998). Refleksiia profesiinoho stanovlennia v yunatskomu vitsi [Reflection on professional development in adolescence]. Praktychna psykholohiia ta sotsialna robota Practical Psychology and Social Work, 6-7, 80-83, S.81 [in Ukrainian]. 
4. Derkach, A.A., \& Selezneva, E.V. (2007). Akmeologiia v voprosakh $i$ otvetakh (Uchebnoe Posobie) [Acmeology in questions and answers]. Moscow : MPSI, Voronezh : NPO MODEK [in Russian].

5. Dzhems, U. (1982). Lichnost [Personality]. Iu.B. Gippenreiter \& A.A. Puzyrei (Red.), Psikhologiia lichnosti - Psychology of Personality (pp. 61-70). Moscow : Izd-vo MGU [in Russian].

6. Druzhynina, I.A. (2010). Mistse profesiinoi identychnosti ta identyfikatsii u profesiinomu prostori praktychnoho psykholoha [The place of professional identity and identification in the professional space of a practical psychologist]. Visnyk Kharkivskoho natsionalnoho pedahohichnoho universytetu imeni H.S. Skovorody. Psykholohiia - Bulletin of Kharkiv National Pedagogical University named after GS Frying pans. Psychology, 37, 99-108. Kharkiv : KhNPU [in Ukrainian].

7. Dubrovyna, Y.V., Akymova, M.K., \& Borysova, E.M. (1995) Rabochaia knyha shkolnoho psykholoha. [School Psychologist's Workbook] Y.V. Dubrovynoi (Red.). Moscow : Mezhdunarodnaja pedagogicheskaja akademija [in Russian].

8. Yevdokimova, O.O. (2009). Psykholohichni zasady vyshchoi tekhnichnoi osvity [Psychological principles of higher technical education]. Kharkiv : Nove slovo [in Ukrainian].

9. Zeer E.F. (2005). Psikhologiia professii [Psychology of professions]. Moscow : Akademicheskii Proekt, Fond «Mir» [in Russian].

10. Kokun, O.M. (2012). Psykholohiia profesiinoho stanovlennia suchasnoho fakhivtsia [Psychology of professional development of a modern specialist]. Kyiv : DP «Informaciino-analitichne ahenstvo» [in Ukrainian].

11. Kon, I.S. (1980). Psihologija starsheklassnika [Psychology of a high school student]. Moskow : Prosveshhenie [in Russian].

12. Leontjev, A.N. (1975). Dejatelnost. Soznanie. Lichnost [Activity. Consciousness. Personality]. Moscow : Politizdat [in Russian].

13. Lozhkin, H.V., \& Volianiuk, N.U (2008.). Profesiina identychnist v konteksti marhinalnoi povedinky [Professional identity in the context of marginal behavior]. Socialna psihologija Social psychology, 3, 123-130 [in Ukrainian].

14. Povarenkov, Ju.V. (1991). Psihologija professionalnogo stanovlenija lichnosti (osnovy psihologicheskoj koncepcii professionalizacii) [Psychology of professional formation personality (the basis of the psychological concept professionalization)]. Kursk : Izd-vo KGPI [in Russian].

15. Rohov, E.Y. (1999). Nastolnaia knyha praktycheskoho psykholoha (ucheb. posobye 2-e yzd., pererab. y dop. ) [Handbook of a practical psychologist]. Knyha 2: Rabota psihologa so vzroslymi [Work of a psychologist with adults]. Moscow : Humanytarnoe yzdatelstvo: Tsentr VLADOS [in Russian].

16. Semychenko, V.A. (2000). Priorytety profesiinoi pidhotovky: diialnisnyi chy osobystisnyi pidkhid? [Training priorities: activity or personal approach?] Neperervna profesiina osvita: problemy, poshuky, perspektyvy - Continuing professional education: problems, searches, prospects. In I.Ya. Ziaziun (Red.). (pp.176-203 ). Kyiv: Vipol [in Ukrainian].

17. Symaniuk, E.E. (2005). Psikhologicheskie barery professionalnogo razvitiia lichnosti [Psychological barriers to professional development of the individual]. Moscow : Moskovskii psikhologo-sotsialnyi institut [in Russian].

18. Shnejder, L.B. (2007). Lichnostnaja, gendernaja i professional'naja identichnost': teorija $i$ metody diagnostiki [Personal, gender and professional identity: theory and diagnostic methods] Moscow : Izd-vo Mosk. soc.-psihol. in-ta [in Russian].

19. Adamek, R.L. (1971). Social Structure, Identification and Change in Treatment-Oriented Institution. Socialization, 162-188.

20. Barbour, J., \& Lammers, J. (2015) Measuring professional identity: a review of the literature and a multilevel confirmatory factor analysis of professional identity constructs. Journal of Professions and Organization, 2(1), 38-60. https://doi.org/10.1093/jpo/jou009 
21. Ely, J.D. (1997). Community and the Politics of Identity: Toward the Genealogy of a NationState Concept. Stanford Humanities Review, 5 (2). Retrieved from http://www.stanford.edu/group/SHR/

22. Neary, S. (2014) Professional Identity: What I Call Myself Defines Who I am. Career Matters, 2 (3), 14-15.

23. Pratt, M., Rockmann, K., \& Kaufmann, J. (2006) Constructing Professional Identity: The Role of Work and Identity Learning Cycles in the Customization of Identity among Medical Residents. Academy Of Management Journal, 49(2), 235-262. https://doi.org/10.5465/amj.2006.20786060

24. Waterman, A.S. (1982). Identity development from adolescence to adulthood: Anextension of theory and a review. Devel. Psychology, 3 (18), 341-358. https://doi.org/10.1037/0012$\underline{1649.18 .3 .341}$

\title{
MODERN METHODS AND MEANS OF THE PROFESSIONAL SELF-IDENTITY OPTIMIZATION OF THE FUTURE PSYCHOLOGIST Inna Boychenko \\ Researcherat the Department of Youth Problems Research \\ State Institute of Family and Youth Policy \\ 17a, Esplanade Str., Kyiv, Ukraine, 01023 \\ boych@ukr.net, http://orcid.org/0000-0002-2607-5612
}

\begin{abstract}
The article presents the analysis of approbation results of effective formation means of professional self-identity and its components among future psychologists, first of all through activation of personal self-development, shaping self-identity idea, development of cognitive, emotional, motivational and behavioral components of professional self-identity as a whole. The tasks of the formative experiment on optimization of professional psychologists' self-identity included: 1) development of the program of professional self-identity optimization for future psychologists; 2) bringing inadequately inflated self-esteem level among the students-psychologists during educational and professional training to an adequate state through the use of the optimization program; 3) reduction of anxiety and negative affect experience of future psychologists during training with the help of the program; 4) raising the cognitive activity level of future psychologists during training with the help of the program. A training program to optimize the formation of professional self-identity among the future psychologists has been developed. It contains the following active socio-psychological methods: discussions, roleplaying games, psycho-gymnastic techniques, trainings with homework, methods of individual independent work. The purpose of the training program is to adjust the levels of psychological and pedagogical component development of future psychologists in the course of their professional selfidentity formation. Tasks of the training program: 1) mastering professional self-identity knowledge that is necessary for students psychologists in their effective future activity; 2) acquaintance of future psychologists with methods and techniques of diagnosis of psychological characteristics of personality that affect the formation of professional self-identity; 3) mastering the skills and abilities to perform specific professional tasks that arise in the process of future activities, using their own professionally significant qualities. The first module was aimed at improving cognitive activity of future psychologists, the second one was to correct their self-esteem, and the third module was aimed to correct their emotional state. To determine the effectiveness of the program for optimizing the process of professional self-identity of future psychologists, we conducted a comparative analysis of the levels of personal component development in the control and experimental groups.

Keywords: professional self-identity, personal components of professional self-identity, components of professional self-identity personal components, training program for optimization of professional self-identity, future psychologist.
\end{abstract}

